\title{
Renal agenesis, bilateral
}

INSERM

\section{Source}

INSERM. (1999). Orphanet: an online rare disease and orphan drug data base. Renal agenesis, bilateral. ORPHA:1848

Bilateral renal agenesis is the most profound form of renal agenesis (see this term), characterized by complete absence of kidney development, absent ureters and subsequent absence of fetal renal function resulting in Potter sequence with pulmonary hypoplasia related to oligohydramnios, which is fatal shortly after birth. 